\title{
The impact of the logistics management in customer satisfaction
}

\author{
Amine GHOUMRASSI \\ The Bucharest University of Economics Studies, Bucharest, Romania \\ ghoumrassi.amine@hotmail.fr \\ Gabriela TIGU \\ The Bucharest University of Economics Studies, Bucharest, Romania \\ gabriela.tigu@ase.ro
}

\begin{abstract}
Logistics management is one of nowadays tools to face economic challenges; it's a mix of business and core activities of the organization. The supply and distribution activities integrated together form what's known as logistics activities. The logistics activities within a business organization attempt to satisfy customers through achieving the time and location related market challenges and also through the cost of the service provided as well as the quality, taking into consideration customers needs and purchase power. Customer satisfaction is important because it provides marketers and business owners with a metric that they can use to manage and improve their businesses. Customer satisfaction is also a way to determinate the continuity of the business or of a product life by measuring the loyalty of the customers. If the customers are happy and satisfied, it will ensure the continuity of sales which means the continuity of the business. In the past customer satisfaction was more focused on requirements such as quality and reliability reducing costs of poor quality. In mid 50's the production costs were continuously increasing, The way to maintain the company's position within a changing market and increase profit starts by focusing on the service provided to the customer and on decreasing the cost, logistics activities became the backbone of these organizations that target the customer satisfaction while achieving competitive advantage. This study aims to show the impact of the logistics management on customer satisfaction in small and mid-sized Algerian industrial companies, by interviewing the companies managers and everybody in charge of the logistic process, the interview questions will be based on some literature review issues.
\end{abstract}

Keywords: logistics activities, customer satisfaction, small and mid-sized companies, logistics management, customer service.

\section{Introduction}

Since the beginning of "customer service revolution" almost 25 years ago, business's research has focused on customers, especially customer satisfaction. Business consultants, corporations and operational management have all worked together to identify the characteristics of organizations that consistently please their customers, to develop tools that monitor customer satisfaction, and to build continuous quality improvement systems that respond to consumer feedback.

Although the research has been conducted by and for the corporate world, customer service and satisfaction is not limited to the private sector only, but every company that is interested in determining its success and ensure its continuity.

During the 50's-60's the product costs were continuously increasing which lead to many crises and low purchase power, the business consultants and operational 
management kept searching for a tool that can take care of customer satisfaction as well as cost and quality. In addition, the highly competitive environment at that time made companies look for a competitive advantage. Researchers arrived to the conclusion that logistics management has the potential to assist the organization in the achievement of both, customer satisfaction and cost / productivity advantage and a value advantage (Christopher, 1998).

Logistics management is the governance of supply chain functions. Logistics management activities typically include inbound and outbound transportation management, fleet management, warehousing, materials handling, order fulfillment, logistics network design, inventory management, supply/demand planning, and management of third party logistics services providers. To varying degrees, the logistics function also includes customer service, sourcing and procurement, production planning and scheduling, packaging and assembly. Logistics management is part of all levels of planning and execution strategic, operational and tactical. It is an integrating function, which coordinates all logistics activities, as well as integrates logistics activities with other functions including marketing, sales manufacturing, finance, and information technology.

This paper aims to enlarge the debate concerning the different logistics solutions

implemented by industrial companies to increase customer satisfaction and to determine their impact. In particular this research, by means of semi-structured interviews, aims to identify and propose new links between logistics management solution theory and customer satisfaction. The semi-structured interviews involved 12 small and mid-sized Algerian industrial companies from different sectors. Their 22 supply chain and logistics senior managers were interviewed to identify their understanding of what they believe to be important within their suppliers and how logistics management is important for them in order to be satisfied customers.

\section{Literature review}

There are many conferences and papers concerning customer satisfaction and how it can be improved from a marketing view. Nowadays it is a sure thing that customer satisfaction has many aspects and is not just linked to the quality and the costs of the product (Kristianto et al., 2012; Meybodi, 2015). It has been ascertained, in particular, that a logistic dimension is important in customer satisfaction. Lai and Cheng (2009, p. 111), mentioned for instance, its link to the ability to deliver the right amount of right product, at the right place, at the right time, in the right condition with the right information.

25 years ago, some researchers showed a positive relationship between customer satisfaction requirements and delivery and logistics solutions (Sharma et al., 1995; Choi and Eboch, 1998; Cermak et al., 2011; Beamon, 1999). Cermak et al. (2011) even discussed the fact that customers can participate in the specification and delivery of the services. In this sense, suppliers have to react to customer's demand in a timely manner increasing their abilities to master all the processes including the logistic ones. Logistics has been defined as being a very important tool for integrating the internal operations of an organization with the supply chain processes to increase customer satisfaction. For instance, Bowersox et al. (2002) investigated all the supply management processes which can affect logistics and customer satisfaction and reported that a logistical value proposition and logistics have a big impact on customer satisfaction leveraging on order processing, inventory 
management, transportation, handling and packaging and production, as well as facility network design.

Zhang et al. (2005) demonstrated a quantitative inquiry carried out in US industrial organizations that logistics flexibility is a fundamental requirement for responding to changing customer needs.

Lastly, logistics nowadays increased customer's attention, according to the results of the

PICBE | 409 literature review.

However, in the literature, there's a lack of understanding of what these solutions are for, in what way and to what degree they affect the customer. In particular there's no trace of quantitative simulations that can demonstrate the relative importance of these issues to the customers.

Anyhow, from the literature review, some specific theoretical key issues were emerged. Each key have been linked with the main literature as per the following list:

1- K1: customer satisfaction is affected by warehouse and inventory management solutions (Sharma et al., 1995; Beamon, 1999; Bowersox et al., 2002; Sbihi and Eglese, 2010; Genchev et al., 2011)

2- K 2: customer satisfaction is affected by the control and integration of the supply chain into the company's operations (Bowersox et al., 2002; Cermak et al. 2011; Del Baldo, 2011; Vona, 2011)

3- K3: customer satisfaction is affected by the sharing and managing of common Information Communication Technology (ICT) processes (Gunasekaran et al., 2004; Bienstock et al., 2008)

4- K4: customer satisfaction is affected by the sharing and managing of common key performance indicators (KPIs) and performance data (Gunasekaran et al., 2001; Tracey and Leng Tan, 2001; Gunasekaran et al., 2004; Khan et al., 2012)

5- K5: customer satisfaction is affected by the mastery of knowledge and skills linked to logistics from the supplier (Zhang et al., 2005; Cermak et al. 2011; Lun et al., 2015)

6- K6: customer satisfaction is affected by the green logistics solutions adopted by the supplier (Fleischmann et al., 2000; Rogers and Tibben-Lembke, 2001; Sbihi and Eglese, 2007)

Our questions were based on these keys, means that we conducted a semistructured interview, using questions that were made out of these keys, and which the answers will lead into answering or explaining these issues

\section{The logistics management:}

Logistics management is a supply chain management component that is used to meet customer demands through the planning, control and implementation of the effective movement and storage of related information, goods and services from origin to destination. Logistics management helps companies reduce expenses and enhance customer service.

The logistics management process begins with raw material accumulation to the final stage of delivering goods to the destination.

By adhering to customer needs and industry standards, logistics management facilitates process strategy, planning and implementation. 


\section{Customer satisfaction:}

Customer satisfaction measures how well the expectations of a customer concerning a product or service provided by a company have been met.

Customer satisfaction is an abstract concept and involves factors such as the quality of the product, the quality of the service provided, the atmosphere of the location where the product or service is purchased, and the price of the product or service. Businesses often use customer satisfaction surveys to gauge customer satisfaction. These surveys are used to gather information about customer satisfaction. Typical areas addressed in the surveys include:

- Quality of product

- Value of product relative to price - a function of quality and price

- Time issues, such as product availability, availability of sales assistance, time waiting at checkout, and delivery time

- Atmosphere of store, such as cleanliness, organization, and enjoyable shopping environment

Customer satisfaction provides an important indicator of consumer purchase intention and loyalty, among the mostly collected indicator, their principal use is twofold:

1- Within the organization, analysis of the collected data sends a message about the importance of tending to customers and ensuring that they have a positive feedback and experience with the company goods and services.

2- Throughout market share, it can indicate how well a firm is performing, customer satisfaction is the best indicator of how likely it is that the firm's customers will make further purchases in the future.

Most of researchers described the customer satisfaction as the most important indicator of company existence and product life.

\section{Relations between customer satisfaction and logistics management:}

All researchers and business consultant agreed that the logistics management is consists of all parties (including manufacturers, marketers, suppliers, transporters, warehouses, retailers, and even customers) directly or indirectly involved in fulfillment of a customer's need. The main objectives of the logistic are to improve the overall organization performance and customer satisfaction by improving products or service delivery to customer.

The relation between the customer satisfaction and logistics management has many indicators; one of the most import indicators is the cost of the product.

The logistics analyze aims to reduce the cost from suppliers to final user, taking into consideration the quality and the time, two of the major customer satisfaction indicators are the costs and the waiting time. Both customer satisfaction indicators are implied in the logistics process which result to a cheap product (using a cheap raw material, choose the cheapest transportation method, high production with low labor costs, low cost storage and delivery). 


\section{Methodology}

This research has been carried out within 12 medium and small-sized industrial companies that have their headquarters in Algeria. For each company the supply chain senior manager was interviewed. In 4 companies out of 12 , the supply chain managers work side-by-side with the logistics managers. Therefore these were interviewed too, ultimately 22 managers were interviewed.

A list of 30 small and mid-sized company based on Algiers was put thought the scanning process applying the criteria bellow and only 12 companies passed. The selection was based on the criteria given below:

1. Must be medium or small-sized industrial enterprises. In this way they have better control of the supply chain because of their contractual power (over small- to medium-sized enterprises).

2. Must be very committed to the development of their supply chain and sharing knowledge linked to logistics improvements, such as lean and agile systems, specific software and electronic systems.

3. Must measure supplier performance through similar indicators. Shared indicators include on-time delivery, products damaged and packaging compliance, customer service and satisfaction and after sales service.

4. Must be interested into the development of their supply chain from a sustainability and green point of view. (The companies have been suggested by a private consulting firm specialized in operations management. They have been doing consultancy in these companies for many years helping them increase customer satisfaction and improve logistic processes)

5. Must be located in Algiers

Table 1. Kind of products those companies produce
\begin{tabular}{|l|l|}
\hline Company & Product \\
\hline 1 & Electronics assembly \\
\hline 2 & Air filters \\
\hline 3 & Oil pumps \\
\hline 4 & Motorcycle components \\
\hline 5 & Phone's assembly \\
\hline 6 & Diesel engines \\
\hline 7 & Automotive components \\
\hline 8 & Air compressors \\
\hline 9 & Special filters for big engines \\
\hline 10 & Hot water heaters \\
\hline 11 & Automatic machines for constructions \\
\hline 12 & Customized engines \\
\hline
\end{tabular}

Source: Authors' own research. 
Since all the companies were based in Algeria, we decided that the industrial law and regulations shouldn't affect the process of choosing logistics solutions.

Table 2. The questions used at the interview and the notes.

\begin{tabular}{|c|c|c|}
\hline $\mathbf{Q}$ & Open Question & Notes \\
\hline 1 & $\begin{array}{l}\text { What's the reverse logistics solution executed } \\
\text { by your suppliers and that can affect your } \\
\text { customer satisfaction? }\end{array}$ & $\begin{array}{l}\text { Study all the reverse solutions } \\
\text { during product life cycle, and } \\
\text { also after the end of the product } \\
\text { life cycle }\end{array}$ \\
\hline 2 & $\begin{array}{l}\text { What are the green logistics used by your } \\
\text { suppliers that can affect your customer } \\
\text { satisfaction? }\end{array}$ & $\begin{array}{l}\text { Following the law and the } \\
\text { regulations, using the eco- } \\
\text { friendly or green initiatives, } \\
\text { packaging recycle, eco-friend } \\
\text { transportation }\end{array}$ \\
\hline 3 & $\begin{array}{l}\text { Does the logistics knowledge level or your } \\
\text { supplier affect your customer satisfaction? }\end{array}$ & $\begin{array}{l}\text { It's very important, since the } \\
\text { supplier is the first step into the } \\
\text { logistic chain, so yes, the } \\
\text { logistics skills is very important }\end{array}$ \\
\hline 4 & $\begin{array}{l}\text { Does sharing results and company data affect } \\
\text { your customer satisfaction? }\end{array}$ & $\begin{array}{l}\text { Confidential/ Can only discuss } \\
\text { few data regarding the logistics } \\
\text { performance }\end{array}$ \\
\hline 5 & $\begin{array}{l}\text { Does sharing results and data concerning the } \\
\text { information technology process affect your } \\
\text { satisfaction? }\end{array}$ & $\begin{array}{l}\text { Discuss only the information } \\
\text { technology integrated into the } \\
\text { logistics process }\end{array}$ \\
\hline 6 & $\begin{array}{l}\text { What are the transportations and packaging } \\
\text { implemented by your suppliers and can affect } \\
\text { your customer satisfaction? }\end{array}$ & $\begin{array}{l}\text { Discussed, products handling, } \\
\text { and safe transportation, and } \\
\text { ease of handling the products }\end{array}$ \\
\hline 7 & $\begin{array}{l}\text { Does your supplier integration and control of } \\
\text { the supply chain, affect your customer } \\
\text { satisfaction? }\end{array}$ & $\begin{array}{l}\text { Demonstrate and investigate } \\
\text { how the integration can lead } \\
\text { into increasing the performance } \\
\text { linked to customer satisfaction, } \\
\text { also a good handling of the } \\
\text { supply chain will always lead } \\
\text { into a satisfied customer } \\
\text { because it takes into } \\
\text { consideration time, cost, and } \\
\text { quality. }\end{array}$ \\
\hline
\end{tabular}

Source: Authors' own research.

The open questions are linked somehow into the 6 key issues. The interview created lot of qualitative data, to easy analyze it, we use the software Nvivo, the data was coded and labeled in order to clarify the meaning of some information (Lofland and lofand 1995, Bazeley and Jackson 2013).

\section{Result discussion}

According to all the interviewed, in order to improve the customer satisfaction their suppliers should use some lean and agile solutions, most of the respondent underlined that the focus is to increase delivery on-time performance and at the same time reduce the delivery time.

Fifteen out of 22, believed that the lean solutions are necessary, indeed customer satisfaction derives from having always the right amount of the product at the right time 
with the less cost, they also believe that it should be packed in easy handling package, so humans or normal machine can carry out the packaging and handle the storage.

Six out of 22 believed that the suppliers and customer to sub-supplier should use the same information technology, they said that it doesn't matter what type of system everybody use but it should have the same KPI's set for each ally.

Mostly, 21 out of 22 believes in good results and good business when their supplier have a good skills or knowledge in logistics solutions, it can help them to easily set target and performance key, it also reduce them the operational risk management, since the supplier is aware of all the logistics functionalities and has a good knowledge of logistics solutions.

Again, 22 out of 22, says that it's very important for the product and the packaging to meet the market law or regulation, especially when it comes to the environment, It's very important that their suppliers use the eco-friendly or green packaging and transportation, this affect directly the customer emotion.

Table 3. Coding and grouping the qualitative data

\begin{tabular}{|c|c|c|c|}
\hline Responses & Initial coding & $\begin{array}{l}\text { Concordant } \\
\text { respondent }>9\end{array}$ & Focused coding \\
\hline \multirow{4}{*}{$\begin{array}{l}\text { Data from interviews } \\
22 \text { is the number of } \\
\text { interviewed persons }\end{array}$} & $\begin{array}{l}\text { Using agile solutions for } \\
\text { transportation }\end{array}$ & $15 / 22$ & \multirow{4}{*}{$\begin{array}{l}\text { Fragile and } \\
\text { leanness logistics } \\
\text { solutions }\end{array}$} \\
\hline & $\begin{array}{l}\text { Using easy to handle } \\
\text { packaging and storage }\end{array}$ & $15 / 22$ & \\
\hline & $\begin{array}{l}\text { Use effective and leanness } \\
\text { reverse logistics in case of } \\
\text { defective product }\end{array}$ & $14 / 22$ & \\
\hline & & Average: 14.66 & \\
\hline \multirow[t]{3}{*}{$\begin{array}{l}\text { Data from interviews } \\
22 \text { is the number of } \\
\text { interviewed persons }\end{array}$} & $\begin{array}{l}\text { Sharing the company KPI's } \\
\text { set up at least for delivery } \\
\text { time/ successful delivery/ } \\
\text { defective delivery }\end{array}$ & $8 / 22$ & \multirow[t]{3}{*}{$\begin{array}{l}\text { Sharing ICT and } \\
\text { logistics } \\
\text { performance } \\
\text { measurement } \\
\text { system }\end{array}$} \\
\hline & $\begin{array}{l}\text { Using the same logistics } \\
\text { solutions and information } \\
\text { technology from supplier to } \\
\text { the customer to the sub- } \\
\text { supplier }\end{array}$ & $6 / 22$ & \\
\hline & & average:7 & \\
\hline \multirow[t]{3}{*}{$\begin{array}{l}\text { Data from interviews } \\
22 \text { is the number of } \\
\text { interviewed persons }\end{array}$} & $\begin{array}{l}\text { Suppliers with good logistics } \\
\text { skills and knowledge level }\end{array}$ & $19 / 22$ & \multirow[t]{3}{*}{$\begin{array}{l}\text { Suppliers with } \\
\text { good logistics } \\
\text { skills }\end{array}$} \\
\hline & $\begin{array}{l}\text { Suppliers with good logistics } \\
\text { skills analyze that can react in } \\
\text { timely manner and re- } \\
\text { designer sub suppliers }\end{array}$ & $21 / 22$ & \\
\hline & & Average: 20 & \\
\hline
\end{tabular}




\begin{tabular}{|l|l|l|l|}
\hline $\begin{array}{l}\text { Data from interviews } \\
22 \text { is the number of } \\
\text { interviewed persons }\end{array}$ & Packaging respecting all laws & $22 / 22$ & $\begin{array}{l}\text { Green or eco } \\
\text { friendly logistics } \\
\text { and reverse } \\
\text { logistics }\end{array}$ \\
\cline { 2 - 3 } & $\begin{array}{l}\text { Eco-friendly and recycling } \\
\text { packaging }\end{array}$ & $21 / 22$ & \\
\cline { 2 - 3 } & $\begin{array}{l}\text { Reverse logistics for } \\
\text { environmental problems }\end{array}$ & $18 / 22$ & \\
\cline { 2 - 3 } & & Average: 20.33 & \\
\hline
\end{tabular}

PICBE $\mid 414$

Source: Authors' own research.

\section{Conclusion}

This research study started with a literature review of six keys issues, that relate customer satisfaction with logistics management and solutions, these keys were used to design a semi-structured interview, using open questions.

Managers were asked to explain their point of view regarding what kind of logistics solutions their suppliers would have to use in order to increase their customer satisfaction.

Based on the answers, we ranked five in order of importance: 'suppliers with logistics skills and knowledge' was identified as the most important category that lead to increase the customer satisfaction, managers require that their suppliers must have a good knowledge and logistics skills to adapt to any last minute changes into the product life cycle. Followed by 'green logistics solutions or eco-friendly and reverse logistics' which mostly refer to packaging and using eco-friendly transportation method, it's very important to take into consideration the environment, for that managers says that their suppliers must use a very modern packaging method that is very eco-friendly, the final packaging nowadays is important as much as the quality of the product, since most of the world population are concerned and manipulated by environment defenders associations. In place 3rd, 'Fragile and leanness logistics solutions' lean and agile solutions have also a big role, according to the literary review, this is the most important category that links directly to the result, of course in customer mind, buying a product means, delivery on-time and quickness of delivery. Last, 'Sharing ICT and logistics performance measurement system', it's unexpected that the sharing of ICT and logistics performance measurement system will be ranked as not important as the other categories, this view explained by managers as it's impossible to have one system for all the clients, taking into consideration the supplier view, that has too many customers, it's impossible for him to have one system that works with all of his customers.

At the end, this research has several limitations, which leads for a new research in the future using more samples, assorted with surveys and result analyzes. This research has brought light to some of the interested categories that are implanted by the logistics management solutions, which according to this research might affect the customer satisfaction. The research results leads to the fact that the logistics management has a big impact on customer satisfaction and companies using logistics management are having higher percentage of customer satisfaction than companies that doesn't. Being told that customer service and customer satisfaction are implemented in logistics management process, this means that the logistic management connect all the steps into one process that by the end its objective is to satisfy customers, as well as the optimization of the company results. 


\section{References}

Bazeley P., Jackson K. (2013), Qualitative data analysis with NVivo, Sage Publications Limited, London.

Beamon B.M. (1999), "Measuring supply chain performance", International Journal of Operations and Production Management, 19(3), 260-295.

Dekker R., Bloemhof J., Mallidis I. (2012), "Operations Research for green logistics-An overview of aspects, issues, contributions and challenges", European Journal of Operational Research, 219(3), 671-679.

Genchev S.E., Richey R.G., Gabler C.B. (2011), "Evaluating reverse logistics programs: suggested process formalization". International Journal of Logistics Management, 22(2), 242-263.

Gunasekaran A., Patel C., Tirtiroglu E. (2001), "Performance measures and metrics in a supply chain environment", International journal of operations and production Management, 21(1/2), 71-87.

Khan, M.S., Naumann E., Williams P. (2012), "Identifying the key drivers of customer satisfaction and repurchase intentions: An empirical investigation of Japanese B2B services", Journal of Consumer Satisfaction, Dissatisfaction and Complaining Behavior, 25(3), 159-178

Sharma A., Grewal D., Levy M. (1995), Customer satisfaction/logistics interface", Journal of Business Logistics, 16(1), 14-21.

Gunasekaran A., Patel C., Mcgaughey R.E. (2004), “A framework for supply chain performance measurement", International journal of production economics, 87(3), 333-347.

Zhang Q., Vonderembse M.A., Lim J.S. (2005), “Logistics exibility and its impact on customer satisfaction”, International Journal of Logistics Management, 16(1), 71-95. 